Cadernos de História, Belo Horizonte, v. 22, n. 36, Junho de 2021

DOI: https://doi.org/10.5752/P.2237-8871.2021v22n36p80-97

\section{A CONVERSÃO AO CRISTIANISMO IMPOSTA AOS JUDEUS NO REINADO De Dom Manuel I de Portugal}

Maria Regina T. WeCKWERth Universidade Federal de Alfenas mrtww00@hotmail.com

Paulo Romualdo Hernandes Universidade Federal de Alfenas paulorh_mancini@hotmail.com

\title{
Resumo
}

Este estudo investiga a presença dos judeus em Portugal tendo como problema central a conversão ao cristianismo imposta no governo do rei Dom Manuel I. O estudo visita a historiografia e as ordenações Afonsinas e Manuelinas, além de buscar em Damião de Góis, que descreveu o reinado do felicíssimo rei Dom Manuel, no ano de 1566, informações importantes sobre a expulsão e a pressão imposta pelo rei para a conversão dos judeus ao cristianismo. A investigação considerou que a conversão forçada foi provocada por questões políticas e econômicas, resultando em violência contra os judeus, tanto por serem obrigados a deixar sua crença, como por se verem obrigados a permanecer em Portugal como Outro, o cristão-novo, sendo perseguidos pelo Mesmo, o cristão-velho.

Palavras-chave: História de Portugal; Dom Manuel I; Judeus; Cristão-novo.

Recebido em 22 de setembro de 2020.

Aprovado em 16 de outubro de 2020. 
Cadernos de História, Belo Horizonte, v. 22, n. 36, Junho de 2021

DOI: https://doi.org/10.5752/P.2237-8871.2021v22n36p80-97

\section{THE CONVERSION TO Christianity imposed ON JeWS IN THE REIGN OF DOM MANUEL I of Portugal}

MARIa Regina T. WeCKWERTH Universidade Federal de Alfenas mrtww00@hotmail.com

Paulo Romualdo Hernandes Universidade Federal de Alfenas paulorh_mancini@hotmail.com

\begin{abstract}
This study investigates the presence of Jews in Portugal having as a central problem the conversion to Christianity imposed by the government of King Dom Manuel I. The study visits the historiography and the Aphonsine and Manueline ordinances, in addition to looking at Damião de Góis, who described the reign of the most fortunate King Dom Manuel, in the year 1566, important information about the expulsion and the pressure imposed by the King for the conversion of the Jews to Christianity. The investigation considered that the forced conversion was caused by political and economic issues, resulting in violence for the Jews, both for being forced to leave their belief, and for being forced to remain in Portugal as Other, the New Christian, being persecuted by the Same, the old Christian.
\end{abstract}

Keywords: History of Portugal; Dom Manuel I; Jews; New Christian. 


\section{INTRODUÇÃo}

Península Ibérica, lar de muitos povos, desde fenícios, egípcios, celtas, romanos, germanos a judeus. Estes teriam vindo para Portugal a partir do século V, para a historiografia de modo geral, segundo Azevedo (1975). No entanto, o autor não julga temerário supor terem vindo, os judeus, para Portugal, ainda com os fenícios. Os judeus foram forçados pelo rei Dom Manuel a se tornarem cristãos, convertendo-se em cristãos-novos. Embora a conversão ao cristianismo não se apresentasse como fato novo na vida dos judeus ou correligionários de outra fé, após a instituição do cristianismo como religião universal, no Concílio de Nicéia, no século IV, parece-nos permitido dizer tratar-se de um fato novo para os judeus portugueses serem convertidos à força por Dom Manuel I, em 1497, pois foram impedidos por todos os meios de abandonar o reino, mesmo aqueles que se prontificavam a seguir outras direções e abandonar seus bens e raízes constituídos em Portugal, por recusarem desertar de sua fé.

Considerando o percurso desde o período Tardo Antigo, quando ocorreu o Concílio de Nicéia e a Igreja Católica instituiu o cristianismo como religião universal, configurou-se, desde então, a evolução da Igreja como portadora da palavra divina. Elemento fundamental no sentido de uma aliança necessária e legitimadora com a Coroa, na qual o rei passa a ser o representante de Deus num reino unificado pela fé em Cristo, segundo os dogmas instituídos pela Igreja Apostólica Romana (FRIGHETTO, 2012). Esse princípio paradigmático será mantido ao longo dos próximos quinze séculos, aproximadamente.

Desde o período central da Idade Média, século XII, quando as cruzadas assumem papel preponderante na instituição do cristianismo, a conversão obrigatória a uma religião estranha a própria fé constituiu-se num problema. As punições advindas da recusa em converteremse, tais como a expulsão ou a Inquisição, e o corolário consequente das suas atividades nos levam a buscar subsídios em períodos bastante distantes do período manuelino.

O objetivo deste trabalho é fazer um resgate na historiografia do não respeito ao diverso, à diferença de crença, na história ibérica, com conotações político-econômicas que levaram Dom Manuel a obrigar os judeus a se tornarem cristãos para mantê-los em Portugal.

As condições sob as quais os judeus viveram em Portugal configuravam-se como absolutamente de conveniência para o Estado. No entanto, segundo o parâmetro da história cultural, percebe-se que o judeu fora visto, sobretudo pela Igreja Católica, como o Outro. Desde o século XIV, com o advento da peste, amplia-se a propaganda antissemita e também a perseguição ao judeu, que passa a ser satanizado, caracterizado e representado como o anticristo.

A perseguição e a culpa atribuída aos judeus pelas pestes, os satanizando, teve cunho ideológico político-econômico. $\mathrm{Na}$ segunda metade do século $\mathrm{XV}$, em 1481, quando da ascensão ao trono por Dom João II, o Príncipe Perfeito, a Coroa Portuguesa passa por profundas reformulações em diversos âmbitos do Reino, promovendo a reorganização política, social e econômica lastreadas no princípio centralizador. O Rei ordena, o Rei manda, o Rei determina e exige ser obedecido. Este rei aceitará a vinda, para Portugal, de judeus que foram expulsos de Castela, em troca de benefícios financeiros para seu reino. Esses aspectos serão acentuadamente refletidos no reinado de seu sucessor, Dom Manuel I. Esse monarca, atendendo exigência do Rei Fernando, de Espanha, como condição para 
casar-se com sua filha Isabel, assinou um decreto, em cinco de dezembro de 1496, de expulsão dos judeus do reino, dando-lhes a opção de conversão ao cristianismo como acontecera na Espanha (NOVINSKY [et al], 2015, p. 41). Houve um grande êxodo de judeus do reino por não pretenderem se converter ao cristianismo, o que teria preocupado o rei Dom Manuel, afinal: "um êxodo tão expressivo de judeus prejudicaria a economia portuguesa. Assim, em abril de 1497, ordenou que nenhum judeu saísse do Reino, obrigando todos a se converterem ao catolicismo" (NOVINSKY [et al], 2015, p. 42).

Como resultado da conversão forçada dos judeus, Dom Manuel I torna seu reino predominantemente cristão ao trazer os judeus para o seio da Igreja, aspecto que parece demonstrar a importância da manutenção da comunidade judaica, adequada aos objetivos do monarca, quer no sentido de sua afirmação perante as autoridades eclesiásticas, quer no sentido do apoio econômico representado por essa comunidade: hábeis financistas, mercantilistas e investidores do reino.

Dom Manuel I compromete-se, por meio de decretos, a não inquirir comportamentos religiosos dos cristãos convertidos por vinte anos; em 1512, dilata esse prazo por mais dezesseis anos, ocasionando problemáticas conturbações no reino. No entanto, manifestações antissemitas em Portugal, sobretudo por parte de dominicanos e franciscanos, propiciaram que Dom Manuel solicitasse ao papa Leão X, em 1515, bula de estabelecimento do Tribunal da Inquisição em Portugal, promovendo uma frontal mudança na posição da Coroa em relação aos cristãos-novos, na medida em que os destituiu de todos os privilégios concedidos em 1497, quando submeteram os judeus à conversão forçada.

\section{A importância econômica dos judeus para o reino de Portugal}

Num oceano de forças dominantes, o poder, por razão ou por necessidade, estabelece regras que se manifestam como ondas em altas e baixas marés. Permeia-se, assim, a aceitação, mesmo que reservada e condicional, do diferente e da diversidade cultural - nesse caso, a cultura hebreia. Em contrapartida, promovem-se atos de intransigência exprobratória ao não admitido, o que, por estar fora da cultura estabelecida pelo poder vigente, deixa marcas profundas: Segregação, abandono, perseguições e perdas de natureza diversa. Tal contexto revela-se intermitentemente presente na vida dos judeus viventes na Península Ibérica, desde os primeiros séculos da Era Cristã e ainda no século XVI.

Todavia, esse não foi um ato novo ou inusitado na vida da comunidade hebreia. Conforme Novinsky, a violência que emergiu no período moderno "não foi um fenômeno que afluiu de um momento para outro, mas a continuidade de um processo, cujos antecedentes podemos buscar no remoto Reino Visigodo" (NOVINSKY, 2010, p. 5). Segundo Sancovsky (2010), judeus já haviam se estabelecido na Península Ibérica desde o tempo da civilização fenícia, aos 586 a.C., quando se tornaram exilados e refugiados da Judeia; posteriormente, em decorrência da destruição do Templo de Jerusalém; e, aos 70 d.C., com a invasão romana. Foram testemunhas oculares das incursões visigodas e de acordos definidos por Roma na Hispânia visigoda, da vigência da monarquia ariana e da conversão desta ao catolicismo, no reinado de Recaredo, em 586. Passados 35 anos, teriam eles, os judeus, a imposição da conversão ao cristianismo no reinado visigodo de Sisebuto, aos 621 (SANKOVSKY, 2010). 
Novinsky descreve que, com os primeiros monarcas portugueses, os judeus desfrutaram de uma vida extremamente independente, quer jurídica, social ou cultural, de seus costumes, tradições e religião. A religião não os impedia de exercer cargos oficiais importantes junto aos monarcas. Cita, a propósito, o cargo de Ministro da Fazenda no reinado de Dom Diniz, exercido e acumulado pelo arabi-mor dos judeus. Diz, ainda, que a atitude independente do povo português e a mobilidade da Igreja eram marcas de distinção dos demais povos e, ainda que a Igreja tentasse exercer sua influência canônica interferindo nas judarias, havia uma relação recíproca entre judeus e cristãos, com as naturais influências e trocas culturais (NOVINSKY, 2009).

A considerar-se o exposto por Novinsky, fica estabelecida a ideia de uma relação perfeitamente equilibrada, circunstancialmente pontuada por tentativas de interferência. No entanto, como salienta Kayserling, tais relações vinham permeadas pela desconfiança contra os hebreus, mesmo em tempos de Afonso Henriques (1140-1185), primeiro rei de Portugal. Segundo o autor:

É interessante observar que, numa mesma lei, se alternam liberdades e restrições. Em alguns casos, os judeus são equiparados aos nobres em direitos e posições; em outros, são considerados inferiores até aos odiados mouros (KAYSERLING, 2009, p. 37).

Quanto ao aspecto das boas relações entre judeus e cristãos em Portugal, parece haver um consenso entre vários historiadores: Novinsky (2009), Bethencourt (2004), Sancovsky (2010), Tavares (1993). No entanto, o que se observa é somente uma tolerância por parte dos soberanos - tolerância essa pautada em interesses, conforme observaremos, quer pelos conhecimentos em áreas ligadas às finanças, quer pelas habilidades em áreas das ciências médicas, astrologia e afins, quer pela disponibilidade de recursos econômicos que atendessem necessidades e emergências no reino, como o financiamento de guerras.

Herculano (2002), em seu estudo realizado no século XIX, manifestava parecer, retomado um século depois por Novinsky, que os judeus de Portugal tinham uma vida distinta de outros povos europeus e os descreve como nação à parte, regida por direito público e civil especial, a exemplo das Ordenações Afonsinas, primeiro código regular das leis pátrias. Cita, ainda, viverem em bairros afastados, segregados, em judarias ou judiarias, cuja constituição análoga ao governo das populações cristãs era regida por magistraturas locais e, acima destes, o arabimor, alto funcionário, encarregado pela intermediação nos negócios do povo hebreu com o monarca, exercendo superintendência, nomeações, administração e fazenda das comunas. Isso lhes conferia, até certo ponto, liberdades e garantias, entretanto, pontuadas por uma sequência de limitações em questões civis. Conforme alude Kayserling (2009), os judeus sempre viveram como povo tributário, isolados, discriminados pela religião e pelos costumes. Todavia, exerceram desde o princípio da monarquia portuguesa grande influência no reino, desfrutando de tolerância e apoio dos monarcas.

Nesse aspecto, Kayserling (2009) assevera a propósito de um dos primeiros reinados de Portugal -o terceiro - no qual Dom Sancho II (1223-1224) manteve, mesmo tendo por inimigos os poderes eclesiásticos, a contratação de judeus em cargos públicos, à revelia da lei promulgada por seu pai, Afonso II (1211-1223), que não os queria nesses postos. Agrega o autor: "Não o fez certamente por preferi-los aos cristãos", porém, "tal como outros reis 
da Península Ibérica, por se encontrar entre eles os financistas mais aptos e hábeis; o que iria impedi-lo de atraí-los para sua corte?" (KAYSERLING, 2009, p. 38). Prática repetida nos reinados de Dom Dinis (1279-1325), Dom Afonso IV (1325-1357), Dom Pedro I (13571367) e Dom Fernando (1367-1383), que atribuíram aos judeus cargos de tesoureiros-mores, ou seja, exerceram função que nos dias de hoje corresponderia ao de Ministros da Fazenda (HERCULANO, 2002).

Dom Fernando (1367-1383) exerceu um reinado conturbado; prenunciou tempos sombrios para os judeus, que, em vista do auxílio fazendário dado ao monarca, tornaramse foco de revoltas e ataques da população até a ascensão ao trono por Dom João I (KAYSERLING, 2009). Esse período foi marcado por manobras políticas que favoreceram a invasão de Dom João I de Castela, em Portugal, obrigando o Mestre de Avis, futuro rei Dom João I, de Portugal, a encabeçar a revolta contra os castelhanos. Essa revolta perdurou mesmo após o Mestre de Avis ter assumido o trono em 1385, assegurando a independência portuguesa e trazendo consigo uma nova dinastia (MARQUES, 1980). Quando, em 1391, deu-se a perseguição e morte de inúmeros judeus na Guerra Civil Castelhana, solicitou-se ao rei o acolhimento dos judeus espanhóis em Lisboa e Dom João I fez publicar uma ordenação "segundo a qual os judeus do seu país, tanto os nativos como os recém-chegados, fossem protegidos de todos os modos, proibindo ainda, baixo pena de castigo, que fossem presos ou recambiados" (KAYSELING, 2009, p. 73). Nesse período, voltaram a desfrutar a liberdade de seguir sua religião e seu direito privado, protegidos por bulas de ampla proteção, mas restritos a leis claramente segregatórias.

No reinado de Dom Duarte (1433-1438), menos tolerados, continuaram suas atividades de cobrança e arremate de impostos. Nesse ínterim, o povo reclamava, com alguma razão, de atos vexatórios e de exploração por parte dos judeus, segundo Herculano (2002).

Com Dom Afonso V (1438-1481), o quadro transfigurou-se e os judeus foram protegidos como nunca haviam sido por monarcas anteriores. Segundo Kayserling (2009, p. 97), "parece que todas as leis canônicas e restrições vigentes tivessem sido repentinamente suspensas". Os judeus tiveram maior liberdade, ambicionando o poder e negligenciando o cumprimento de deveres próprios da religião mosaica, conforme o autor. Tais excessos, na opinião de seus adversários políticos, acirraram a ira da população. Herculano (2002) salienta fatos, ocorridos em Lisboa, em fins de 1449, quando jovens da cidade insultaram e maltrataram judeus, levando-os a apelar aos magistrados. Estes, por considerarem os cristãos dignos de castigo, ordenaram que fossem açoitados publicamente, gerando uma revanche feroz, por parte da população, que armada voltou-se contra as judiarias. Segundo Vieira (2020, p. 40),

\footnotetext{
em dezembro daquele ano, após as autoridades de Lisboa punirem um grupo de jovens que havia insultado judeus publicamente, ocorreu um ataque à Judiaria Grande de Lisboa. As casas do local foram saqueadas e depredadas, e alguns judeus foram mortos durante os conflitos. O rei Afonso V conseguiu controlar a situação em pouco tempo com auxílio das forças régias. Dezenas de cristãos foram presos e castigados, estes eram em sua maioria pequenos comerciantes locais. Temos conhecimento de sessenta e nove homens participantes das violências que foram condenados ao exílio em Ceuta (VIEIRA, 2020, p. 40).
}

Nesse período, a população hebreia crescia em número, recém-chegada de Castela. Com fartos recursos econômicos e imiscuídos na percepção das rendas públicas e no comércio, 
incitaram ânimos contrários por parte do clero, da população e também entre os indivíduos acima da plebe, os burgueses em ascensão e os pequenos nobres.

Conforme Pieroni (2000, p. 40), esse rei foi responsável por um conjunto de leis para controle do reino: "Esse corpo legislativo é conhecido como Ordenações Afonsinas, em homenagem ao rei Afonso V". Tais ordenações são fontes incontestes da segregação que viveu esse povo. No livro II, título LXXVI, estabelece "De como os judeus ham de viver em Judarias apartadamente":

El Rei Dom João meu avô de louvada memória em seu tempo fez lei, de cujo o teor é: Dom João pela graça de Deus rei de Portugal e do Algarve. A todos os Juízes, e Justiça dos nossos reinos, que esta nossa Carta virdes, ou o tratado dela em publica forma feita por autoridade de Justiça, saude. Sabede, que nós havemos por informação, que alguns lugares de nossos reinos os judeus, que aí há, não vivem todos apartadamente em suas judarias, segundo é ordenado por nós, e pelos reis, que antes de nós foram; e que alguns deles vivem misticamente entre os cristãos, e andam de noite aos de fora das ditas judarias; do que a nós não praz, nem o havemos por bem feito, se assim é. E porem vos mandamos, que cada hum de vós em vossos julgados façades apregoar, que todos os judeus se vão a morar dentro das judarias, que lhe são apartadas ata certos dias convinha, que lhes pera eles assinardes; e que outro se depois que for noite não saiam fora de suas judiarias. E aqueles que o contrário fizerem vos os prendem, e não os soltes sem nosso mandado; e fazer-lhes tomar para nós todos os seus bens. E se em alguns desses lugares não houver judarias, ou forem tão pequenas, em que todos não possam caber, vós os apartardes, ou lhes acrescente, se pequenas forem, de guisa que possam em elas caber em aqueles lugares, que foram mais conveniente. E nisto sede bem diligentes, e avisados de quisa, que o serviço de Deus, e nosso seja em ele guardado, senão sede certos, que a vos nos tornaremos por ele, e vo-lo estranharemos: unde al nom façades. Dada em cidade de Braga trinta dias de Setembro. El Rey o mandou. Alvaro Gonçalves a fez, Era de mil e quatrocentos e trinta e oito anos. A qual lei vista, e examinada por nós, havemos por boa, e mandamos que se guarde como em ela é conteúdo, e que se entenda nas Vilas grandes, e em outros lugares, onde houver até dez judeus, e daí para cima; porque achamos, que assim foi ordenado por el Rey Dom Pedro de louvada memória em atigos gerais por ele acordados, e terminado nas Cortes, que fez na Vila de Elvas (ORDENAÇÕES AFONSINAS, 1438).

Nota-se que as Ordenações Afonsinas seguem outras ordenações, como no caso do título LXXVI, que reproduz na verdade Carta de Dom João I, avô de Dom Afonso V. Nessa citação, fica clara a segregação em que viviam os judeus desde, pelo menos, o reinado de Dom João I, de 1385 até 1433 . Eles deviam viver em judarias e não podiam sair à noite, sob o perigo de serem presos e ainda perderem seus bens para o reino. O título LXXIIII nos remete a outros fatores que comprovam o caráter econômico da permanência dos judeus em Portugal, segregados em judarias: "De como as comunas de judeus hão de pagar o serviço Real”. Esta ordem foi estabelecida pelo rei Afonso IV, que governou Portugal de 1325 até 1357.

Primeiramente todo judeu desde que for em idade de quatorze anos em diante, e for casado, ou viúvo, pague vinte soldos em cada ano. E a judia que for casada, ou viúva, pague dez soldos. E o judeu, ou judia não paguem nenhuma coisa até que sejam de idade de sete anos; e desde a dita idade de sete anos em diante a judia pague dois soldos e meio, até a idade de doze anos; e o judeu pague cinco soldos, até que seja em idade de quatorze anos. E a judia desde que for em idade de doze anos em diante, e não for casada, e viver em poder do pai, ou da mãe, ou de outrem, ou servir a outrem, pague meio maravedi, que são sete soldos e meio; e se viver por si, pague dez soldos; e o judeu, que for de quatorze anos em diante, e não for casado, e viver em poder alheio, pague um maravedi que são quinze soldos a cada um ano e se viver para si pague vinte soldos (ORDENAÇÕES AFONSINAS). 
O consenso de alguns historiadores - Novinsky (2009), Bethencourt (2004), Sancovsky (2010), Tavares (1993) - de que os judeus em Portugal teriam vida melhor que em outros reinos europeus parece não se sustentar, pois o que se observa de fato é uma aceitação do judeu pautada em interesses políticos e econômicos. Quanto a esse aspecto, Kayserling (2009) reafirma a distinção do povo hebreu em relação aos outros povos, quer em Portugal ou qualquer outra nação, pois os interesses econômicos se acentuaram no reinado de Dom João II, quando, mais uma vez, os judeus expulsos de Castela foram aceitos em Portugal e, depois, por interesses políticos, foram expulsos, também de Portugal, por Dom Manuel. Por fim, por interesses econômicos, foram obrigados a se converter ao cristianismo a fim de não deixarem o reino.

\section{A conversão imposta aos Judeus por Dom Manuel I: QUESTÕES POLÍTICAS E ECONÔMICAS}

O período no qual os judeus espanhóis se refugiam em Portugal, após a expulsão de Castela, em 1492, volta a incitar o processo, aliás, já instaurado, de extrema aversão por parte dos cristãos aos judeus de Portugal. Crise que não era restrita à plebe, mas, extensiva aos grandes e ao clero, no reinado de Dom João II, que por sua vez introduzia profundas reformulações em seu reinado. Considerando o fato de que os judeus apresentavam-se em condições de superioridade nas atividades do comércio e habilidades nas ciências, como assevera Azevedo:

\footnotetext{
O hebreu não somente trazia para a luta pela vida o intelecto muito mais desenvolvido que o competidor cristão; (...) eram eles os médicos, cirurgiões, boticários e astrólogos; da mesma sorte, astrônomos e geógrafos; e com qualquer dessas profissões acumulavam, se havia oportunidade, a usura, cujos proventos thes eram mais seguros e abundantes (AZEVEDO, 1975, p. 35).
}

Com isso, "facilmente triunfavam da rudeza e ignorância da população nativa" (AZEVEDO, 1975, p. 35). Por essa razão, Herculano (2002) defende ser provável o fato de os judeus terem desfrutado de tantos favorecimentos por parte do poder monárquico em Portugal como tesoureiros, conselheiros ou arrendadores de impostos no reino.

Dom João II (1481-1495) assume o reino por abdicação de seu pai Dom Afonso V e é referenciado por seus próprios cronistas como intolerante e cruel com os judeus, nas palavras de Herculano. Repetem-se denúncias e lamentos contra os judeus. Requerimentos em assembleia de 1490 solicitam que os judeus sejam exonerados de suas funções fiscais. Dom João recusa-se formalmente a excluí-los, considerando rendeiros cristãos não menos opressores que os hebreus, alegando não haver cristão habilitado para tais funções e, se havia, exorbitavam nas cobranças para obter lucros (HERCULANO, 2002).

Promulgada a lei de expulsão dos judeus espanhóis, em 31 de março de 1492, grande número de famílias ricas foi acolhido por Dom João II, mediante pagamento de elevados tributos, como nos revela Damião de Góis, em seu livro a Dom Manuel:

Dos quais alguns antes que saíssem de Castela mandaram pedir licença a El Rei Dom João para virem para Portugal, e lhe mandar dar embarcação para suas pessoas, e, bem, o que lhes ele concederem com que lhe pagarem por cabeça (exceto as crianças de mama) oito cruzados, pago em quatro pagas, e os que eram ferreiros, latoeiros, malheiros, e armeiros 
pagavam a metade menos, querendo ficar no Reino, e assim a estes, se declaravam que se queriam ir, como os outros, assinou Dom João tempo limitado em que pudessem estar no reino, e não se saindo no tal tempo, ficassem seus cativos. Destes judeus houve el Rei uma grande soma de dinheiro, porque segundo se afirma entraram nestes reinos mais de vinte mil casais, em que havia alguns de dez e doze pessoas e outros de mais, com o qual dinheiro tinha determinado fazer uma armada para passar em África (DAMIÃO DE GÓIS, 1566).

Aqueles que permaneceram em Portugal, sem as condições de pagamento, foram entregues à servidão, apartados de seus filhos menores, que por ordem de Dom João II foram enviados à Ilha de São Thomé, expostos a uma vida semibárbara, muitos dos quais pereceram. Entre os sobreviventes, dada sua temperança, conquistaram espaços, tornando-se “opulentos colonos daquela fértil possessão" (HERCULANO, 2002, p. 66). Azevedo (1975) nos deixa uma avaliação menos cruel, alegando que "a impressão deixada pela narrativa é a de uma hecatombe herodiana”. Descreve o documento deixado por Herculano: um "Bando de crianças, algumas de colo, lançadas nas praias inóspitas da ilha: sucumbindo à fome ou devoradas pelas feras". De fato, tais crianças eram recebidas pelo senhorio da ilha, que as encaminhava aos colonos locais, e assim seriam criadas no credo cristão, o que naturalmente não invalida a razão condenável do ato joanino, "todavia, menos tétrica", segundo o autor (AZEVEDO, 1975, p. 24).

Dom Manuel I sucede Dom João II ao trono e estabelece novas ordenações, revisando as Ordenações Afonsinas. Comparativamente às Ordenações Afonsinas, as Ordenações Manuelinas, segundo a autora Hunold Lara, se equivalem na estrutura, com algumas revisões e atualizações. Todavia, as Ordenações Manuelinas são apresentadas como escritas em nome do rei, "como se dele sempre tivessem sido emanadas, diferentemente da anterior que chegava a reproduzir textos publicados por outros monarcas" (LARA, 1999, p. 32), como foi visto nas citações anteriores. Nas ordenações Manuelinas, livro II, título LXI, temos o termo de expulsão dos judeus de Portugal: "Que os judeus e mouros forros se saiam destes Reynos e nom morem, nem estem nelles”.

\footnotetext{
Nós muito certo, que os Judeus e Mouros obstinados no ódio da nossa Santa Fé Católica de Cristo Senhor, que por sua morte nos redimi, tem cometido, e continuamente contra ele cometem grandes males, e blasfêmias em esses nossos reinos, as quaes não tão somente a eles, que são filhos de maldição, em quanto na dureza de seus corações estiverem, sem causa de mais condenação, mas ainda a muitos cristãos fazem apartar da verdadeira carreira, que é a Santa Fé Católica; por estas, e outras mui grandes e necessárias razões, que nos a está movem, que a todo cristão são notórias e manifestas, avida madura deliberação com o Nosso Conselho, e Letrados, Determinamos, e Mandamos, que da publicação desta Nossa Lei, e Determinação ate todo o mês de Outubro do ano do Nosso Senhor de mil e quatrocentos e noventa e sete, todos os Judeus, e Mouros forros, que em Nosso Reino houver, se saiam fora dele, sob pena de morte natural, e perder fazenda pera quem os acusar. E qualquer pessoa que passado o devido tempo tiver escondido algum Judeu, ou Mouro forro, per esse mesmo feito queremos que perca sua fazenda, e bens, pera quem o acusar, e Rogamos, e Encomendamos, e Mandamos por nossa benção, e sob pena de maldição aos Reis Nossos Sucessores, que nunca em tempo algum deixem-no morar nem estar nestes nossos Reinos e senhorios deles, judeus e mouros (ORDENAÇÕES MANUELINAS, p. 212)
}

A expulsão dos judeus de Portugal oferecia interesses políticos e econômicos para Portugal e Espanha. O rei Fernando, da Espanha, impôs como condição para D. Manuel casar-se com sua filha Isabel, para que expulsasse os judeus de suas terras, pois, segundo 
Novinsky [et al] (2015, p. 41), "percebia o prejuízo que causaria ao seu país a permanência de uma população ativa, culta e laboriosa no reino vizinho de Portugal”. O Monarca português atendeu essa exigência porque queria estabelecer os laços permanentes com a Espanha, "e assim garantir a união entre as coroas: portuguesa e espanhola, mediante seu casamento com a princesa Isabel, conforme acordo fechado com os Reis Católicos” (SOUZA, 2018, p. 105). Essas alianças matrimoniais eram práticas comuns nos países ibéricos e tinham como objetivo o poder de governar as duas coroas.

O próximo título do livro II, o título XLII, demonstra vantagens para os judeus se tornarem cristãos: Como o cristão que foi judeu deve herdar a seu pai, mãe e parentes. Dom Manuel, que em 1496 daria prazo até outubro de 1497 para os judeus deixarem Portugal, fez todo tipo de pressão para que eles não deixassem o reino e se convertessem forçadamente ao cristianismo (COSTA, 2007). Uma das causas de toda a pressão para os judeus se converterem e, assim, não deixarem Portugal, segundo Damião de Góis (1566), é que eles eram muito hábeis. Entre outras tarefas, produziam armas, o que poderia equipar muitos inimigos dos reinos de Portugal e Castela, entre eles a França e a Inglaterra e, sobretudo os muçulmanos. Conforme o livro V, título LXXXII, das Ordenações Manuelinas: "Dos cristãos novos, e mouros, e cristãos mouriscos, que se vão para a terra de mouros, ou para as partes da África, e dos que os levam" é possível perceber essa preocupação com os mouros.

\footnotetext{
Defendemos e mandamos que nenhum cristão novo que fosse judeu, ora seja Nosso Natural, ora estrangeiro, se vá, nem passe de Nossos Reinos para nenhuma Terra de Mouro, sob pena de quem o contrário fizer perder toda sua fazenda, e ser cativo, sendo tomado no próprio auto sua fugida e ida, ou em qualquer outro auto porque conhecidamente pareça eles se quererem ir, ou fugir para as ditas partes contra esta Nossa defesa. E nessas mesmas penas incorrerem os que se forem com sua casa movida para qualquer lugar d'Além em África, posto que de Cristãos seja, sem Nossa licença. E defendemos que nenhuma pessoa leve os ditos cristãos novos para as ditas partes, como dito é. E qualquer pessoa que lhe for provado que os levou para Terra de Mouros, morra por isso morte natural, e perderá toda sua fazenda. [...] E mandamos que nenhuma pessoa de qualquer condição e qualidade que seja, leve os ditos Mouros, nem cristãos novos sobreditos fora de nossos reinos por mar nem por terra. E qualquer pessoa que os levar para terra de mouros, o lhe for provado que os levou, morra morte natural, e perderá toda sua fazenda, e o navio, posto que não seja seu: e se os levar para outra qualquer parte que não seja terra de mouros, ou se provar que os queria levar para terra de mouros, perderá o dito navio em que os levou, ou queria levar, posto que não seja seu, e mais toda sua fazenda, e será degredado quatro anos para os lugares d'Além em África; e se alguma pessoa os tiver, ou se provar que os teve encobertos em alguma casa ou lugar, incorrerá na mesma pena de perdimento de fazenda, e degredo. As quaes fazendas e navios, nos casos sobreditos serão a metade para Nossa Câmara, e a outra metade para quem os descobrir e acusar (ORDENAÇÕES MANUELINAS, p. 244)
}

Essa proibição está relacionada, sobretudo, ao perigo que representavam os mouros para Portugal e o perigo ainda maior de que os judeus, ou cristãos-novos, ou criptojudeus, com seus conhecimentos na fabricação de armas, entre outros, pudessem se juntar aos mouros. Ainda segundo Damião de Góis (1566), no século XV, os judeus, que haviam entrado em massa em Portugal no reinado de Dom João II, quando foram expulsos de Castela, tornaram-se fundamentais na economia portuguesa, nos investimentos, na produção e nos conhecimentos científicos.

Segundo nos dá a entender Obradó (2006), desde sua inserção na comunidade cristã, os judeus convertidos passaram a representar para os cristãos-velhos um problema 
socioeconômico, graças, no entendimento dos cristãos de sangue, como se nomeavam, ao empenho dos cristãos convertidos em conquistar espaços e aproveitar as muitas oportunidades que se apresentavam. Esses cristãos-velhos acreditavam que os cristãos convertidos promoviam uma competição desleal, a qual era fortalecida por atitudes de opressão e exploração exercida sobre eles, valendo-se do apoio que lhes outorgavam os nobres, prelados e reis, para que os judeus, habituados ao êxodo, se fixassem em Portugal por vontade própria ou não. Soma-se a isso, a função de recolhedores de impostos agregando mais hostilidades e alimentando a propaganda contra os convertidos, bem como tumultos por parte das camadas mais populares. Além disso, as camadas economicamente mais favorecidas também temiam ser suplantadas pelos convertidos, que pareciam prosperar resolutamente.

\section{A pedagogia do Medo Perante os JUdeUs e A REVOLTA AO CRISTÃO CONVERTIDO}

Segundo Santo Agostinho, a cegueira tinha levado os judeus a rejeitarem Jesus Cristo e, na condição de deicidas, foram castigados por Deus com a dispersão pelo mundo. No entanto, apesar de suas culpas, eram considerados pelo santo os depositários das tradições sobre as quais havia sido erigido o cristianismo e, embora não merecedores, haveriam de ser respeitados pelos cristãos, como testemunhas da verdade e da historicidade das profecias cristológicas. Desse modo, "não poderiam ser forçados à conversão ao cristianismo, a esta estavam já destinados quando chegasse o fim dos tempos” (OBRADÓ, 2006, p. 302). Mesmo assim, as perseguições continuaram; afinal, aceitar o judeu e sua crença era um ato cristão fundamentado em Santo Agostinho e não de respeito à diferença.

Parece haver uma face pouco considerada que nos remete ao contexto no qual o judeu foi inserido em Portugal, depois expulso e, por fim, forçado a converter-se ao cristianismo: A forma como os judeus e, depois, os cristãos-novos eram percebidos não somente pelos governantes, mas também pelas pessoas com quem conviviam, seus vizinhos, a sociedade portuguesa. É importante compreender o contexto mental, tutelado pela Igreja com seus dogmas de fé, sob o qual vivia a população europeia ocidental nos séculos XIV a XVI. Nessa época, fatores subjacentes como a insegurança diante do desconhecido, o temor de morrer de fome, os terrores gerados pela peste e pelas guerras e tantos outros medos eram projetados sobre o Outro - o não cristão, o estranho e o desconhecido. Assim sendo, eram esses os efetivos causadores das calamidades anunciadas, os bodes expiatórios, culpados pelos castigos que todos recebiam, geralmente advindos de um Criador punitivo e insatisfeito com suas criaturas por acolherem em seu meio os inimigos de Cristo, os judeus.

Quanto ao medo, nesse período histórico, Delumeau (1996) sugere a necessidade de duas averiguações: A primeira, dos medos espontâneos que afetavam grande parte das coletividades, manifestando-se de maneira permanente - por exemplo, o medo do mar e o manuseio de barcos em situações de tormentas por aqueles que cruzavam oceanos nas expedições marítimas portuguesas, com o claro risco para a vida. Do outro lado, os medos cíclicos, manifestados em relação às pestes, penúrias, fome, miséria, aumentos de impostos, guerras etc. Medos permanentes não excluíam medos cíclicos; uns e outros quase sempre se permeavam. 
Uma segunda averiguação remete aos medos refletidos, nascidos de questionamentos acerca da própria vida e das razões de sua infelicidade, estimulados pelos homens da Igreja. O que podemos concluir é que, sobre os medos naturais, nascidos em circunstâncias de fato amedrontadoras, construíram-se outros medos, quiçá irremediáveis porque nascidos de um delírio construído. A Igreja se impõe nessa oportunidade como a única e verdadeiramente capaz de mediar e remediar, por meio da fé apostólica cristã, o difícil caminho em direção da tranquilidade e da felicidade verdadeira. Entretanto, apresenta-se, factualmente, um caminho para violências e rupturas de toda ordem. Instaura-se o que se poderia denominar a pedagogia do medo na Europa Ocidental, que vem associada à Peste Negra, propiciando o momento ideal para instaurá-la (DELUMEAU, 1996).

A Peste Negra, flagelo que acometeu a Europa, repetiu-se de tempos em tempos, por quatro séculos, de 1348 a 1720. Segundo Delumeau (1996), é quando se instaura, não só em Portugal, mas por toda a Europa, a perseguição aos judeus, considerados agentes de Satã e culpados pelo flagelo da peste. Essa perseguição é apoiada pelo clero, pelas autoridades civis e pelas massas cristãs. Frades mendicantes, franciscanos e dominicanos contribuíram intensamente para a formação de uma nova opinião contra os judeus, os quais receberam novos títulos nada enobrecedores, sendo, até mesmo, descritos com traços físicos repugnantes e identificados com o demônio (OBRADÓ, 2006).

Em 1348, a primeira grande peste dizimou inúmeras vidas, passando a repetir-se, desde então, a cada ano até o começo do século XVII. No contexto das grandes crises portuguesas, Tereza Ferreira Rodrigues, em sua análise sobre as estruturas populacionais e a economia de Portugal, destaca os efeitos de surtos epidêmicos que se arrastaram de 1504 a 1557. Em 1505, "uma epidemia trazida de Roma a bordo das naus do arcebispo de Braga", a qual se afirmava ter origem tifoide, estendeu-se endemicamente por dois anos em todo o reino, promovendo fome, pestes, esterilidades e centenas de mortes. Em 1507, ressurgiu no Alentejo, "provocando, só aí, mais de 7500 mortes" (RODRIGUES, 1997, p. 194).

A propósito dessas endemias, observamos o medo refletido na prática, quando a Igreja insere, no contexto de suas pregações, Satã e seus agentes. Aquele, identificado nos turcos, judeus, heréticos e feiticeiras, dava-lhes a conotação de um Juízo Final, descrevendo a peste como um dos Cavaleiros do Apocalipse, revestido com a justificativa da punição pelos pecados cometidos. O movimento primário seguia quase sempre em direção da acusação do Outro; alguém seria o responsável. Satã era refletido no Outro, o judeu, o anticristo; sua presença e seus atos abomináveis eram os verdadeiros responsáveis. Estrangeiros, viajantes, marginais e todos aqueles que não se integravam às crenças da comunidade, a exemplo dos judeus, eram isolados como leprosos (DELUMEAU, 1996).

Nesse período, os judeus passaram a ser relacionados, na literatura religiosa, ao anticristo. Alphonso de Spina, franciscano citado por Delumeau, expõe em seu livro Fortalicium fidei ("A fortaleza da fé"), por volta de 1460, a perspectiva escatológica:

Quando surgir o Anticristo, os judeus se reunirão em torno dele e o adorarão como seu deus. Portanto, a conversão vinha de encontro a esse propósito da clerezia: exorcizar os judeus da dominação de Satã pelos poderes da água batismal. [Figuração exemplar desta ideia foi a conversão forçada realizada por Dom Manuel, em 1497]. Era preciso não hesitar em convertê-los à força e, sobretudo, em batizar seus filhos (DELUMEAU, 1996, p. 288). 
Essa mensagem foi inspiradora para Dom Manuel converter as crianças menores de quatorze anos e apartá-las dos pais para serem criadas por famílias cristãs (COSTA, 2007) e, assim, obrigar os pais que não queriam perder seus filhos a se converterem ao cristianismo. Entretanto, eles, em sua maioria, não se tornaram cristãos, mas cripto-judeus, e foram novamente perseguidos e denunciados por seus "vizinhos".

A contrapartida desse ato não parece ter revelado os resultados esperados. À semelhança do ocorrido na Espanha e em tantas outras ocasiões, “acabavam por se rejudaizarem”, tão logo fosse possível, fato que aconteceu desde as primeiras conversões forçadas realizadas ainda no reino Visigodo, no século IV (DELUMEAU, 1996, p. 303). Poderíamos acrescentar que a conversão imposta por Dom Manuel promoveu esse retorno à judaização até mesmo de uma forma consentida pelo próprio monarca, com todas as garantias de proteção sancionadas por ele. Afinal, a conversão forçada imposta por Dom Manuel fora mais uma daquelas ordens que, segundo Hespanha, raramente são postas em prática:

\footnotetext{
O direito real constituiu uma ordem jurídica apenas virtual, mais orientada para uma intervenção simbólica, ligada à promoção da imagem do rei como sumo dispensador da justiça, do que para uma intervenção normativa que disciplinasse efetivamente as condutas desviantes. Esse caráter virtual da ordem penal real explica, por sua vez, o caráter "livresco" da teoria penal que incide sobre ela e a sua aparente insensibilidade aos problemas sociais e humanos da punição (HESPANHA, 1986, p. 7).
}

Os judeus não deixariam de professar sua fé, na prática, por imposição do Rei, ainda que leis lhes obrigassem a isso. Como aponta Borges Coelho, "Dom Manuel abria, com a conversão forçada, um conflito subterrâneo que corroeria a sociedade portuguesa até ao último quartel do século XVIII" (COELHO, 1998, p. 255). Para além do seu reinado, Dom Manuel I parece ter deixado portas entreabertas que facilitaram o acesso da Inquisição em Portugal, realizada por seu filho, Dom João III.

A pedagogia do medo ao judeu, culpado por todos os males pelos quais passavam os cristãos, somada à imposição da conversão e à resistência dos judeus a essa violência, promoveu um conjunto de rebeliões no reinado de Dom Manuel. Essas rebeliões resultaram, segundo Delumeau, do discurso teológico que vinha alimentando e incentivando o ódio contra os judeus, desde o século XIII, por pastores mendicantes. Entretanto, no período que abrange os Quatrocentos, entre a Idade Média e o nascimento do mundo moderno, esse medo parece adquirir colorações mais intensas, reforçando a difusão do Apocalipse, do Juízo Final e do anticristo - figuras que passaram a ser apregoadas mais acentuadamente em sermões, em finais do século XV e primeiros anos do século XVI, afigurando-se intensamente na imaginação dos homens (DELUMEAU, 1996).

Foi nesse contexto que, em Lisboa, onde a peste exterminava boa parte da população, e aproveitando-se da ausência da família real e dos nobres, em abril de 1506, eclodiu a grande rebelião do povo contra os cristãos-novos, que perdurou por três dias, levando à morte um grande número de pessoas, pela superstição e pelo ódio aos cristãos-novos. O fato gerador da revolta teria sido o comentário feito por um cristão- novo, numa cerimônia na Igreja de São Domingos, quando se ouviram gritos anunciando "milagre", diante da visão de um crucifixo banhado de luz. Alguém da assistência, um presumível cristão-novo, teria dito tratar-se apenas de um reflexo - comentário indevido para aqueles que se encontravam num período 
em que a peste gerava todo tipo de malefícios e a esperança manifestava-se em qualquer coisa que encontrassem para se apegar. No entanto, revelou-se suficiente para desencadear a chacina incentivada por dois dominicanos, "João de Mocho de Évora e Bernardo de Aragão o primeiro, médico, e o outro, organista do Convento, atravessaram as ruas com crucifixo na mão, gritando: 'Heresia! Heresia!', concitando todos a exterminar os amaldiçoados hereges” (KAYSERLING, 1971, p. 129).

A cidade ficou sem controle, e até mesmo seu juiz criminal quase perdeu a vida tentando conter a revolta. $\mathrm{O}$ auge do massacre foi a morte de um abastado cristão-novo e coletor de impostos, João Rodrigues Mascarenhas, odiado por obter junto ao rei decretos severos contra o povo, o que revela o caráter econômico da revolta contra o cristão-novo ou cripto-judeu. Mascarenhas, assim como muitos cristãos novos, foi queimado em praça pública como um anticristo. Dom Manuel, avisado sobre o acontecido, em Avis, puniu a todos os envolvidos, a população e inclusive a justiça, condenando à morte os religiosos e participantes no levante.

Dentre as várias versões desse fato, enunciadas por alguns historiadores - Moreno, Azevedo, Ferro Tavares e outros -, Delumeau, contudo, parece agregar um fato novo ao mencionar que aqueles sacerdotes "não foram executados, tendo, sem dúvida, fugido. Trinta e seis anos depois foram reencontrados vivos” (DELUMEAU, 1996, p. 287).

Neste sentido cabe acrescentar a falta de assistência por parte da Coroa, à qual Souza faz menção:

\begin{abstract}
A nobreza e a corte nesses períodos se refugiavam no campo, longe das aglomerações, atendendo as instruções médicas de se afastarem dos espaços mais habitados e de maior fluxo de pessoas. Assim, como resposta a essa (des)assistência da Coroa, esse grupo desfavorecido acabava elegendo os judeus (cristãos-novos) como seus inimigos e possibilitadores dessa epidemia, em virtude de sua mobilidade espacial (SOUZA, 2018, p.251).
\end{abstract}

"Essa tragédia genocida contra os cristãos-novos" (SOUZA, 2018, p. 252), foi amplamente descrita por cronistas da história portuguesa - Gaspar Correa, Damião de Góis, Samuel Usque, Solomon Ibn Verga e Andrés Bernáldes -, embora este último, um dominicano, confessor do rei católico D. Fernando, tenha produzido uma crônica castelhana, Historia de los reyes católicos Don Fernando y Doña Isabel e, introduzido o fato português, salientando o que chamou de "De el alboroto de Lisbona", conforme nos descreve Rodrigo Vieira (2020) em seu estudo historiográfico do chamado Massacre de Lisboa de 1506. Dentre os aspectos conclusivos abordados por Viera em seu estudo destaca-se a afirmação comum a todas as crônicas: "as pregações inflamadas dos Pregadores contra os cristãos-novos sejam um fator, naquele contexto, impossível de ser ignorado para entendermos a adesão popular nos enfrentamentos" (Vieira, 2020, p.118). Segundo o autor, os cronistas, de modo geral, relatam que os padres em suas pregações associavam a peste, a fome e a seca que atingia Portugal, aos judeus. Assim, esses padres, segundo os cronistas, consideravam os cristãos-novos.

Conforme Ibn Verga, que era cristão-novo, em sua crônica, segundo Vieira (2020), deixa transparecer que mantem práticas judaicas, temos que "fome e seca castigavam a cidade de Lisboa naqueles dias anteriores à Páscoa”. Os cristãos-velhos se perguntavam, "por que o Senhor fez isso conosco e em nossa terra, se por causa da culpa desses judeus?”. Entretanto, "quando essas palavras foram ouvidas por membros da Ordem Dominicana, eles procuraram uma forma de ajudar os cristãos naquele momento tão difícil” (apud VIEIRA, 2020, p. 108). 
Segundo Ibn Verga, um padre dominicano, após ouvir essa suposta fala do povo de Lisboa, fez uma pregação dura contra os judeus na capela do Mosteiro de São Domingos, em Lisboa, contra aqueles a quem chamava de "sementes de Israel":

\begin{abstract}
Para atrair atenção dos cristãos-velhos, os frades inventaram um ardil: usando um crucifixo oco com uma abertura na parte traseira e a frente feita de vidro, posicionaram dentro deste uma vela acesa. O crepitar das chamas dentro do crucifixo fez com que os cristãos presentes se prostrassem e chorassem diante do que era dado como um milagre. Em meio ao furor emocionado, os frades anunciaram para os presentes naquela missa: Veja o grande milagre, este é um sinal de que Deus julga com fogo toda a semente judaica (VIEIRA, 2020, p. 108).
\end{abstract}

Para Ibn Verga, cristão-novo, diferente dos outros cronistas cristãos-velhos, o milagre não passou de uma fabricação dos frades. Descreve a cena com riqueza de detalhes para defender sua tese, mesmo não tendo presenciado o fato, pois não estava na cidade quando o suposto milagre havia acontecido (VIEIRA, 2020).

A conversão forçada dos judeus ao cristianismo foi um ato de violência instituída por Dom Manuel I aos judeus, que resistiram a essa violência e, na prática, não se tornaram cristãos, mas cripto-judeus. Esse ato de violência foi provocado por questões políticas e econômicas. O rei Dom Manuel não podia prescindir do apoio dos reis católicos de Castela e Aragão, que exigiam a expulsão dos judeus de Portugal, depois que os haviam expulsado de seus domínios. O rei português não podia, também, prescindir da riqueza, das habilidades na produção, dos investimentos e dos conhecimentos intelectuais dos judeus em seu território. $\mathrm{O}$ aprisionamento dos judeus em Portugal, convertidos forçadamente ao cristianismo, inclusive com medidas legais que os favoreciam, tornou-os "Outro" - o cristão novo, na verdade, o cripto-judeu - a ser combatido pelo "Mesmo", o cristão-velho, de sangue, como diziam os cristãos de Portugal, estabelecendo na prática um clima de intensa violência. Por meio da pedagogia do medo contra os judeus, e também contra os cristãos-novos ou cripto-judeus, propagada pela Igreja Católica, pelos irmãos mendicantes franciscanos e dominicanos, a sociedade portuguesa do século XVI viveu atmosfera de conflitos e violências que será insuflada pela instalação do Santo Ofício em Portugal, em 1536, por Dom João III.

\title{
Considerações Finais
}

A conversão instituída pela Igreja serviu aos propósitos de estabelecer seu poderio sobre os fiéis, mas o monarca Dom Manuel I encontrou nessa alternativa o meio de atender seus propósitos de poder político e econômico. Se a Igreja precisava se estabelecer como donatária dos princípios da fé cristã, reconhecidos universalmente por seus dogmas, a aliança com a Coroa reinante se fazia imprescindível, e foi sob essa aliança legitimadora que papas e monarcas estabeleceram suas regras de bem viver sob o espírito salvífico de Jesus - todos os habitantes do reino unidos por uma só fé. Ao judeu, ao mouro, ao pagão, ao herético, que professavam outra fé, restava a opção: a conversão, senão a expulsão ou a morte.

Dom Manuel I apresenta um fato novo, quer seja, a conversão imposta para que os judeus não deixem o reino, pois embora as ordenações manuelinas garantissem "os quais mouros e judeus os deixaremos ir livremente com todas suas fazendas" (ORDENAÇÕES MANUELINAS, p. 213), na realidade não houve opção para os judeus que queriam partir e seguir livremente sua fé, pois “a 2 de janeiro de 1497 escreveria Dom Manuel para os juízes 
de Buarcos, ordenando-lhes que não deixassem partir por esse porto judeus ou mouros sem autorização" (COSTA, 2007, p. 123), o que deve ter ocorrido em outros portos. Como forma de pressão, o rei mandou tirar crianças judias, de até quatorze anos, de seus pais, para serem criadas na fé cristã, como relata Damião de Góis (1566), o que não ocorreu com os mouros. Essa decisão provocou desespero em muitos judeus, que preferiram se converter à fé cristã para recuperar os filhos. Os mouros tiveram melhor sorte e puderam sair com mais facilidade; alguns judeus conseguiram ir com eles, porque, segundo Damião de Góis relata em sua obra de 1566, ao felicíssimo Dom Manuel, o rei tinha receio de que os estados islamitas causassem problemas para a cristandade em forma de represália. Dom Manuel, no entanto, proibiria aos judeus irem para a terra dos mouros, sob pena de cativeiro e morte para aqueles que os ajudassem.

A conversão forçada dos judeus promoveria violências em Portugal, conforme nos lembra Marcocci, "dez anos após a conversão dos judeus qualquer aspiração de criar coesão entre cristãos-novos e cristãos-velhos, se jamais existiu, desvaneceu-se”, tendo em vista o massacre de 1506, ocorrido em Lisboa (MARCOCCI, 2011, p. 21-22). Clima de violência iniciado, antes ainda, do reinado de Dom Manuel; no período em que reinou Dom João II, dado o grande volume populacional de judeus castelhanos, recepcionados pelo monarca português, em 1492, promovendo a grande instabilidade sócio-religiosa e econômica na sociedade portuguesa, num clima de segregação aos recém-chegados que traziam conhecimentos científicos, recursos econômicos, práticas de produção e viviam nas judiarias como comunidades à parte da comunidade cristã. Dom Manuel, instado pelos Reis Católicos, em fortalecer as relações com a Espanha, por meio de seu matrimônio com Isabel, amplia os conflitos dos cristãos com judeus ao expulsá-los e, ao mesmo tempo, obrigá-los a se tornarem cristãos e assim permanecerem no reino.

Com a instituição das Ordenações Manuelinas - de fato uma recopilação das Afonsinas, com uma série de ajustes - as juderias deixaram de existir, afinal, supostamente, não existiam mais judeus no reino: Haviam cristãos-novos e cripto-judeus, que o rei parece ter insistido em ignorar, inclusive os protegendo por decretos ao longo de trinta e seis anos. $\mathrm{O}$ judeu tornou-se uma propriedade do rei, preservada ou tolerada, na medida das necessidades do reino, enquanto esse protegido pudesse atender ao reino como funcionário da Corte Real. Afinal, eram bons arrecadadores de impostos, excelentes financistas ou prestamistas para as emergências do reino, sendo, inclusive, emprestados para reinos vizinhos em dificuldades. Eram, contudo, expulsos quando a outorga de proteção extrapolava os interesses econômicos, gerando conflitos no âmbito do poder. Sanados os problemas no reino, eram readmitidos. 


\section{FONTES}

GÓIS, D. Chronica do Felicíssimo Rei Dom Emanuel. Lisboa: Casa de Francisco Correa, impressor do Sereníssimo Cardeal Infante, 1566.

ORDENAÇÕES AFONSINAS. Instituto de História e Teoria das Ideias. Universidade de Coimbra. Disponível em: <http://www.ci.uc.pt/ihti/proj/afonsinas/12p461.htm>. Acesso em: 09 jun. 2020.

ORDENAÇÕES MANUELINAS on line. Instituto de História e Teoria das Ideias Universidade de Coimbra. Disponível em: <http://www1.ci.uc.pt/ihti/proj/manuelinas/>. Acesso em: 08 jun. 2020.

\section{REFERÊNCIAS BIBLIOGRÁFICAS}

AZEVEDO, J. L. História dos cristãos novos portugueses. 2. ed. Lisboa: Livraria Clássica Editora, 1975.

BETHENCOURT, F. História das inquisições: Portugal, Espanha e Itália - Séculos XV-XIX. São Paulo: Companhia das Letras, 2004.

COELHO, A. B. Cristãos-novos, judeus portugueses e o pensamento moderno. In: NOVAIS, A. (Org.). A descoberta do homem e do mundo. São Paulo: Companhia das Letras, 1998.

COSTA, J. P. O. Dom Manuel I. Centro de Estudos dos Povos e Culturas de Expressão Portuguesa da Universidade Católica Portuguesa, 2007.

DELUMEAU, J. História do medo no ocidente. São Paulo: Companhia das Letras, 1996.

FRIGHETTO, R. A Antiguidade Tardia: Roma e as monarquias romano-bárbaras numa época de transformação (Séculos II - VIII). Curitiba: Juruá, 2012.

HERCULANO, A. História da origem e estabelecimento da inquisição em Portugal. Porto Alegre: Pradense, 2002.

HESPANHA, A. M. Da “iustitia” à "disciplina”: textos, poder e política no antigo regime. Artigo publicado em número especial do Boletim da Faculdade de Direito de Coimbra em homenagem ao Prof. Doutor Eduardo Correa. Coimbra: Gráfica de Coimbra, 1989.

KAYSERLING, M. História dos judeus em Portugal. São Paulo: Perspectiva, 2009.

LARA, S. H. Ordenações Filipinas - Livro V. São Paulo: Companhia da Letras, 1999.

MARCOCCI, G. A fundação da inquisição em Portugal: um novo olhar. Revista Lusitânia Sacra, Lisboa, v. 23, p. 17-40, 2011. Disponível em: <https://repositorio.ucp.pt/bitstream>. Acesso em: 10 jul. 2018.

MARQUES, A. H. O. História de Portugal: Desde os tempos mais antigos até ao governo do Sr. Pinheiro de Azevedo. 8. ed. Lisboa: Palas, 1980.

NOVINSKY, A. W. Prefácio. In: SANCOVSKY, R. R. Inimigos da fé: judeus, conversos e judaizantes na Península Ibérica, Séc. VII. 2. ed. Rio de Janeiro: Imprinta Express, 2010.

NOVINSKY, A. W. Prefácio. In: KAYSERLING, M. História dos judeus em Portugal. São Paulo: Perspectiva, 2009.

NOVINSKY, A. W [et al]. Os Judeus que construíram o Brasil: fontes inéditas para uma nova visão da história. São Paulo: Planeta do Brasil, 2015

OBRADÓ, M. P. R. Judeu conversos y monarquia: um problema de opinión pública. In: SORIA, 
J. M. N. (Org.). La monarquia como conflito em la corona castellano-leonesa [e.1230-1504]. España: Elece, 2006.

PIERONI, G. Os excluídos do reino: a inquisição portuguesa e o degredo para o Brasil colônia. Brasília: Universidade de Brasília, 2000.

RODRIGUES, T. F. As estruturas populacionais. In: MATTOSO, J. (org.). História de Portugal: No alvorecer da modernidade. v. 3. Lisboa: Printer Portuguesa, 1997.

SANCOVSKY, R. R. Inimigos da fé: judeus, conversos e judaizantes na Península Ibérica, Séc. VII. 2. ed. Rio de Janeiro: Imprinta Express, 2010.

SOUSA, C. T. de, Entre o desterro dos judeus e o fechamento dos portos portugueses no reinado de D. Manuel I (1495 - 1521): os caminhos trilhados pelos cristãos-novos após o édito / Tese (Doutorado) - Universidade Federal de Goiás, Faculdade de História (FH), Programa de PósGraduação em História, Goiânia, 2018.

TAVARES, M. J. P. F. Linhas de força da história dos judeus em Portugal das origens a actualidade. Revista Espacio, Tiempo y Forma, Espanha, série III, t. 6, p. 447-474, 1993. Disponível em: <https://pt.scribd.com/document/379506039/linhasdeforca-historia-judeus-TAVARES-pdf>. Acesso em: 16 jul. 2018.

VIEIRA, R.F.A. de, Cem dias de absolvição no mundo que há-de-vir: Convivência e tensão entre cristãos-velhos e cristãos-novos nas crônicas quinhentistas do "Massacre de Lisboa de 1506"/ Dissertação (Mestrado) - Universidade Federal do Rio de Janeiro, 2020. 